\title{
Bacteriological quality of raw cow milk in Shahrekord, I ran
}

\author{
Abdolmajid Fadaei \\ Department of Environmental Health Engineering, School of Health, Shahrekord University of Medical Sciences, \\ Shahrekord, Iran. Tel: +98-381-3330299, Fax: +98-381-3334678, Email: ali2fadae@yahoo.com \\ Received: 02-02-2014, Revised: 12-03-2014, Accepted: 19-03-2014, Published online: 15-04-2014
}

doi: 10.14202 /vetworld.2014.240-243

How to cite this article: Fadaei A (2014) Bacteriological quality of raw cow milk in Shahrekord, Iran, Veterinary World 7(4): 240-243.

\begin{abstract}
Aim: The aim of this study was to evaluate the rate of contamination with Escherichia coli, coliforms, and Staphylococcus aureus in raw milk from Shahrekord city, Iran.

Materials and Methods: In this study, 300 raw milk samples were collected randomly from five regions, namely northeast, east, southeast, south, and southwest regions of Shahrekord city according to stratified random sampling design. Samples were analyzed for Total plate count (TPC), Staphylococcus aureus, coliform, and E. coli.

Results: Out of 300 samples of raw milk, contamination with coliforms, E. coli, and S. aureus was observed in 237 (79\%), 207 $(69 \%)$ and $125(41.66 \%)$ samples, respectively. The highest rate of contamination was in the samples from southwest region with coliforms, E. coli, and S. aureus were present in 30 (100\%), 29 (96.66\%), and19 (63.33\%) samples, respectively $(\mathrm{p}<0.05)$.
\end{abstract}

Conclusions: Considering the high rate of raw milk contamination with S. aureus, E. Coli, and coliforms, sanitary practice during collecting, transporting, and storage especially in the summer season is recommended.

Keywords: bacteriological quality, contamination, raw milk, sanitary measures.

\section{I ntroduction}

Milk and other dairy products from cows, goats, and sheep are important components of the people diet. Milk do have distinct physical, chemical and biological characteristics and its colour, odour, taste, consistency, freezing point $\left(-0.55^{\circ} \mathrm{C}\right), \mathrm{pH}(6.6)$ and specific gravity $(1,032)$ are characteristics that remain particularly constant [1]. The bacterial contamination of milk not only reduces the nutritional quality but also consumption of such milk threatens health of the society [2]. Milk is also an excellent medium for the growth of different microorganisms, which may cause various food borne diseases.

The disease causing bacteria in the milk are Salmonella spp., Mycobacterium bovis, Corynebacterium spp., Clostridium perfringens, Yersinia enterocolitica, Coxiella burnetii, Brucella, Staphylococcus, Campylobacter jejuni, Mycobacterium avium, Listeria spp., Escherichia coli, and coliforms. Many bacteria could get an easy access to milk and milk products such as $E$. coli and coliforms; they are often used as indicator organisms to confirm the bacterial contamination of milk. Most common pathogens that have been involved in milk borne diseases include Salmonella spp., Staphylococcus aureus, and E. coli. In recent years, there are several studies related to raw milk contamination including: infection with $C$. jejuni, Listeria monocytogenes, and E. coli strain O157 [3, 4], Campylobacter spp., Salmonella spp. and E. coli [5],

Copyright: The authors. This article is an open access article licensed under the terms of the Creative Commons Attribution License (http://creativecommons.org/licenses/by/2.0) which permits unrestricted use, distribution and reproduction in any medium, provided the work is properly cited.
C. jejuni [6], E. coli, coliforms, S. aureus [4]. The quality and safety of raw milk can be evaluated by assessing hygiene indicator microorganisms. Total coliform, E. coli and S. aureus are used as hygienic parameters for milk production, as they indicate the conditions of raw milk obtaining and storage, and inadequate handling during the manufacturing process. These microorganisms are usually associated with food borne diseases and outbreaks, as recorded by official health organizations [7].

The presence of these pathogenic bacteria in milk appeared as main public health concerns, especially for those people who still drink raw milk [8]. It therefore became the aim of the study to determine the presence of contaminating micro-organisms in the milk produced by small scale dairy farmers in a typical in Shahrekord, Southwest Iran South area where milking is done by hand.

\section{Materials and Methods}

Samples: A total of 300 samples of raw milk (milk collection station) were collected from different places (North-east, East, Southeast, South, and South-west) of Shahrekord city. At each location, samples of approximately $300 \mathrm{ml}$ milk were taken aseptically from the bulk milk container into sterile glass bottles.

Procedure: According to the recommended procedures (pour plate method) colony counting of the bacteria was done. The Eosine Methylene Blue (EMB) and blood agar media were inoculated and kept at $37^{\circ} \mathrm{C}$ for 24-48 hours. For identification of coliforms, and $E$. coli, the differential media, such as TSI, urea, and Simmon citrate were inoculated. For the isolation and 
Table-1: Contamination of raw cow milk samples by coliform, E. coli and S. aureus

\begin{tabular}{llllll}
\hline Seasons & Region & Sample & \multicolumn{3}{c}{ No. of positive sample (\%) } \\
\cline { 3 - 6 } & & & Coliform & E. coli & S. aureus \\
\hline \multirow{2}{*}{ Summer } & Northeast & 30 & $21(70)$ & $19(63.33)$ & $14(46.66)$ \\
& East & 30 & $29(96.66)$ & $20(66.66)$ & $11(36.66)$ \\
& Southeast & 30 & $22(73.33)$ & $21(70)$ & $5(16.66)$ \\
& South & 30 & $28(93.33)$ & $24(80)$ & $7(23.33)$ \\
\multirow{4}{*}{ winter } & Southwest & 30 & $30(100)$ & $29(96.66)$ & $19(63.33)$ \\
& Northeast & 30 & $17(56.66)$ & $11(36.66)$ & $8(26.66)$ \\
& East & 30 & $22(73.33)$ & $18(60)$ & $18(60)$ \\
& Southeast & 30 & $23(76.66)$ & $21(70)$ & $15(50)$ \\
\multirow{2}{*}{ Total } & South & 30 & $19(63.33)$ & $19(63.33)$ & $10(33.33)$ \\
& Southwest & 30 & $26(86.66)$ & $25(83.33)$ & $18(60)$ \\
& - & 300 & $237(79)$ & $207(69)$ & $125(41.66)$ \\
\hline
\end{tabular}

identification of E. coli, the enriched sample was cultured on selective medium Levine Eosin Methylene Blue (EMB) Agar and incubated at $37^{\circ} \mathrm{C}$ for $24 \mathrm{~h}$. Morphologically, typical colonies (at least 4/plate) producing metallic sheen were taken into nutrient broth for further identification. Biochemical tests were performed to confirm E. coli using Gram staining, Catalase test, Indole, Methyl red, Voges-Proskauer test, Nitrate reduction, Urease production, Simmon's citrate agar and various sugar fermentation tests. For isolation and colony counting of $S$. aureus the medium blood agar and DNase media were inoculated and incubated at $35^{\circ} \mathrm{C}$ for 24 hours, the catalase and coagulase test, were performed too. The colonies were counted using colony counter and the number was recorded as colony forming unit/ml (CFU). For testing, 5 dilutions of milk samples, $1,0.1,0.01,0.001$ and $0.0001 \mathrm{ml}$ were used. Aseptically, $1 \mathrm{ml}$ of milk was added to the sterile test tube containing $9 \mathrm{ml}$ of sterile distilled water, mixed properly by cyclometer, $15 \mathrm{ml}$ of medium was poured in the plate containing $0.1 \mathrm{ml}$ of sample and shake to mix thoroughly and uniformly with the agar medium. The agar was allowed to be solidified and the petri-dishes were incubated at $37^{\circ} \mathrm{C}$ for 48 hours. A negative control was prepared using plate count agar only. The plates were placed on a colony counter and the number of bacterial colonies was recorded. The blood agar and DNase test media were inoculated and incubated at $37^{\circ} \mathrm{C}$ for 24 hours [9, $10]$. On the pasteurized samples, the lactose broth with dilution of 1, 0.1, 0.01 was prepared and incubated at $37^{\circ} \mathrm{C}$ for 24 hours. For identification of S. aureus, on each blood agar and EMB media, $0.1 \mathrm{ml}$ of milk sample was inoculated. In case of observing any colony, identification of $S$. aureus was intended.

Statistical analysis: Data were analyzed using descriptive statistics and Chi-square,Mann-Whitney and Kruskal-Wallis.

\section{Results and Discussion}

In this research, total of 300 raw milk sample was studied. In the raw milk samples, contamination with coliforms, E. coli, and S. aureus was observed in 237 (79\%), $207(69 \%)$ and $125(41.66 \%)$, respectively (Table-1). Report given by Nihar in India indicated, that of the 144 samples, Staphylococcus was found in
$47 \%$, whereas Streptococcus and E. coli in $32 \%$ and $21 \%$ of the samples respectively [11].Another report revealed that out of 135 samples, 25 samples were found to be contaminated with Staphylococcus 14 and E.coli 11 [12]. Report on contamination of the raw milk samples in Malayer city of Iran was as follow: E. coli $75 \%$, Enterobacter $42 \%$, Klebsiella $36 \%$ and S. aureus $52 \%$ [13]. The most rate of contamination was in the samples from southwest region with coliforms, E. coli, and S. aureus $30(100 \%), 29(96.66 \%)$ and $19(63.33 \%)$, respectively $(\mathrm{p}<0.05)($ Table- 1$)$. The rate of contamination of raw milk prepared during summer with coliforms, E. coli, and S. aureus with 30 (100\%), 29 $(96.66 \%)$ and19 $(63.33 \%)$, respectively. Indeed, they were more than those prepared in winter with coliforms, E. coli, and S. aureus with 26 (86.66\%), 25 $(83.33 \%)$ and $18(60 \%)$, respectively $(\mathrm{p}<0.05)$.In Nowary and Italay 55\%,43\% samples of cow milk contaminated with $S$. aureus, respectively $[14,15]$. In Malaysia, Thaker and colleagues [16] indicated that $90 \%$ of the examined raw milk were contaminated by coliform bacteria and $65 \%$ were E. coli. When the number of isolates in the raw milk are compared in two seasons of the year, it is noticed that numbers of the detected organisms in the summer is higher than the winter season. The reason could be that in the summer the ambient temperature is high and lacking of refrigeration in the situation of long distance milk transportation helps the situation $[17,18]$.

Table-2 shows the highest rate of isolates in the raw milk orderly as follow: coliforms, $E$. coli, and $S$. aureus. The highest mean value of Total Plate Count was found in milk from the southwest region with $1.91 \times 107 \pm 2.8 \times 10^{3} \mathrm{cfu} / \mathrm{ml}^{-1}$, while the lowest mean value of $1.1 \times 104 \pm 2.8 \times 10^{3} \mathrm{cfu} / \mathrm{ml}^{-1}$ was detected in milk obtained from the southeast region. The results for coliforms, E. coli, and S. aureus contamination in raw milk are shown in Table-2. Counts for coliforms, $E$. coli, and S. aureus were an average count of $1.4 \times 105 \pm$ $2.2 \times 10^{3}, \quad 2.1 \times 10^{3} \pm 101$, and $1.3 \times 10^{3} \pm 137 \mathrm{cfu} / \mathrm{ml}^{-1}$, respectively. Detection of $E$. coli in milk often reflects manure contamination, soil and contaminated water, and poor hygienic practices in dairy environment although environmental coliforms have also been detected in milk. E. coli and coliform bacteria are often used as indicator microorganisms, and the presence of E. coli a risk that other pathogens may be present in the 
Table-2: Mean counts of total plate counts, coliform, E. coli and S. aureus in raw cow milk sample collected from region of Shahrekord city.

\begin{tabular}{lllllll}
\hline Seasons & Region & Sample & \multicolumn{4}{c}{ Mean \pm SD (cfu/ml) } \\
\cline { 3 - 7 } & & & Total plate count & Coliform & E. coli & S. aureus \\
\hline \multirow{2}{*}{ Summer } & North-east & 30 & $7.5 \times 10^{4} \pm 2.5 \times 10^{3}$ & $7.7 \times 10^{4} \pm 2.1 \times 10^{3}$ & $2.0 \times 10^{2} \pm 44$ & $1.5 \times 10^{2} \pm 45$ \\
& East & 30 & $1.9 \times 10^{5} \pm 2.7 \times 10^{3}$ & $1.7 \times 10^{4} \pm 2.7 \times 10^{3}$ & $2.1 \times 10^{3} \pm 120$ & $1.4 \times 10^{2} \pm 78$ \\
& South-east & 30 & $1.5 \times 10^{5} \pm 2.5 \times 10^{3}$ & $1.5 \times 10^{4} \pm 2.05 \times 10^{3}$ & $2.2 \times 10^{3} \pm 400$ & $1.2 \times 10^{3} \pm 111$ \\
& South & 30 & $2.11 \times 10^{5} \pm 2.9 \times 10^{3}$ & $1.11 \times 10^{4} \pm 2.9 \times 10^{3}$ & $2.0 \times 10^{3} \pm 560$ & $1.1 \times 10^{2} \pm 66$ \\
& South-west & 30 & $1.91 \times 10^{7} \pm 2.8 \times 10^{3}$ & $2.8 \times 10^{7} \pm 3.8 \times 10^{3}$ & $3.8 \times 10^{3} \pm 89$ & $2.3 \times 10^{3} \pm 109$ \\
\multirow{3}{*}{ Winter } & North-east & 30 & $6.5 \times 10^{4} \pm 2.1 \times 10^{3}$ & $2.5 \times 10^{4} \pm 2.1 \times 10^{3}$ & $1.9 \times 10^{3} \pm 89$ & $1.2 \times 10^{3} \pm 121$ \\
& East & 30 & $1.7 \times 10^{4} \pm 2.3 \times 10^{3}$ & $1.1 \times 10^{4} \pm 2.3 \times 10^{3}$ & $2.5 \times 10^{3} \pm 359$ & $1.3 \times 10^{3} \pm 102$ \\
& South-east & 30 & $1.1 \times 10^{4} \pm 2.8 \times 10^{3}$ & $1.1 \times 10^{4} \pm 3.8 \times 10^{3}$ & $2.3 \times 10^{3} \pm 149$ & $1.1 \times 10^{3} \pm 89$ \\
& South & 30 & $1.9 \times 10^{5} \pm 2.61 \times 10^{3}$ & $1.9 \times 10^{4} \pm 2.61 \times 10^{3}$ & $2.2 \times 10^{2} \pm 30$ & $2.3 \times 10^{3} \pm 113$ \\
& South-west & 30 & $1.01 \times 10^{3} \pm 2.6 \times 10^{3}$ & $1.5 \times 10^{3} \pm 3.6 \times 10^{3}$ & $2.7 \times 10^{3} \pm 167$ & $1.7 \times 10^{3} \pm 220$ \\
Total & - & 300 & $1.03 \times 10^{6} \pm 2.9 \times 10^{3}$ & $1.4 \times 10^{5} \pm 2.2 \times 10^{3}$ & $2.1 \times 10^{3} \pm 101$ & $1.3 \times 10^{3} \pm 137$ \\
\hline
\end{tabular}

Table-3: Microbial load in milk samples collected from five region of Shahrekord city, I ran

\begin{tabular}{lll}
\hline Milk ranking & $\mathbf{C f u} / \mathbf{m l}$ & $\%$ \\
\hline Excellent & $<30000$ & 11 \\
First-grade & $30000-100000$ & 31.6 \\
Second- grade & $100000-500000$ & 33.9 \\
Third-grade & $500000-1000000$ & 15 \\
Nonstandard & $>1000000$ & 8.5 \\
\hline
\end{tabular}

samples. Presence of S. aureus in milk may originate from mastitic animals [19], or human sources. The total plate count, coliforms, E. coli and $S$. aureus counts for raw milk significantly differed $(\mathrm{P}<0.05)$ amongst the study regions. In similar studies, report on contamination of the raw milk samples in Zimbabwe was similar to this study [20]. Report of the raw milk samples in Greece show that From the 240 milk samples tested, only $5 \%$ were E. coli positive, with mean counts ranged from $2.4 \times 10^{4} \mathrm{cfu} / \mathrm{ml}$. S. aureus was isolated from $24 \%$ of the samples [21]. In Italy, Foschino et al isolated [15] E. coli $\left(2.9 \times 10^{3} \mathrm{cfu} / \mathrm{ml}\right)$, coliforms $\left(9.1 \times 10^{3} \mathrm{cfu} / \mathrm{ml}\right)$ and E. coli in $1.7 \%$ of the samples. Hill et al reported that in New Zealand, [22] E. coli, $99 \%$ of samples tested had counts $<10^{2} \mathrm{cfu} / \mathrm{ml}$ and only $0.7 \%$ were $>10^{3} \mathrm{cfu} / \mathrm{ml}$ and $S$. aureus, the results show that $60 \%$ of the raw milk samples contained $<10^{2} \mathrm{cfu} / \mathrm{ml}$ and $30 \%$ contained between $10^{2}$ and $10^{3} \mathrm{cfu} / \mathrm{ml}$. Overall, contamination of very high number of milk samples could be due to insanitary farms, failing to wash the udders before milking, no mastitis investigates, unhealthy milking vessels and milk containers or tanks, lengthy delivery time, lack of education, and poor staff's hygiene.

By referring to the grading of raw milk contamination of national standard of Iran which is given in the Table- 3 and considering the microbial load, the quality of raw milk was determined as follow: $11 \%$ had very good quality, $65.5 \%$ with first and second grades, that is, with good quality and the rest were of poor quality. Report on contamination of the raw milk samples in Markazi province of Iran was $100 \%$ poor quality $[23,24]$.

\section{Conclusion}

Results from this study showed that raw milk sampled from five different regions in Shahrekord township contained identified pathogens. The prevalence and concentration of the pathogens included in the study were relatively high. Recognition rates for $E$. coli, coliforms, and $S$. aureus were generally higher than those found from in other countries. Recommendations for solving this problem includes i) Educating the farmers on general hygienic practices, quickening the delivery of milk to collection centres, or availing cooling facilities on-farm to improve the microbiological quality of milk, ii) Improve animal health, iii) Improved milking hygiene, iv) pasteurization or boiling of milk prior to consumption. Overall, on farm production of milk must ensure that the milk is produced by healthy animals under generally accepted conditions such as: animal's health, milking health, animals feeding and water, animal's welfare, and environment.

\section{Acknowledgements}

This research was financially supported by Shahrekord University of Medical Sciences (project number 560), Iran.

\section{Competing interests}

The author declare that they have no competing interests.

\section{References}

1. Lues, J. F. R., De Beer, H., Jacoby, A., Jansen, K. E. and Shale, K. (2010) Microbial quality of milk, produced by small scale farmers in a peri-urban area in South Africa, Afr. J. Microbiol. Res. 4(17):1823-1830.

2. Nanu, E., Latha, C., Sunil, B., Prejit, Thomas M. and Venon, K.V. (2007) Quality assurance and public health safety of raw milk at the production point, Am. J. Food Technol. 2: 145152.

3. LeJeune, J. T. and Rajala-Schultz, P. J. (2009) Food safety: unpasteurized milk: a continued public health threat, Clin. Infect. Dis. 48:93-100. 
4. Vahedi, M., Nasrolahei, M., Sharif, M. and Mirabi, A.M. (2013) Bacteriological study of raw and unexpired pasteurized cow's milk collected at the dairy farms and super markets in Sari city in 2011, J Prev Med Hyg . 54: 120-123.

5. Griffiths, M. W. (2010) Milk production and processing in improving the safety and quality of milk. Guelph: Wood head Publishing Limited. $1: 520$.

6. Heuvelink, A.E., van Heerwaarden, C., Zwartkruis-Nahuis, A., Tilburg, J.J., Bos, M.H.and Heilmann, F.G., Hofhuis, A., Hoekstra, T. and de Boer, E. (2009) Two outbreaks of campylobacteriosis associated with the consumption of raw cows' milk, Int J Food Microbiol. 134(1-2): 70-74.

7. Bouazza, F., Hassikou, R., Ohmani, F., Hmmamouchi, J., Ennadir, J., Qasmaoui, A., Mennane, Z., Reda Charof, R. and Khedid, K. (2012) Hygienic quality of raw milk at Sardi breed of sheep in Morocco, Afr. J Microbiol. Res. 6(11): 2768-2772.

8. Claeys, W.L., Cardoen, S., Daube, G., Block, J.D., Dewettinck, K., Katelijne Dierick, K., Zutter, L.D. , Huyghe baert, A., Imberechts, H., Thiange, P., Vandenplas, Y. and Lieve Herman,L. (2013) Herman Raw or heated cow milk consumption: Review of risks and benefits, Food Control, 31:251-262.

9. National Standard of Iran (2002) The milk and milk products. Method of colony counting of bacteria grown at $30^{\circ} \mathrm{C}$. First edition. Institute of standards and industrial research of Iran (ISIRI), Tehran, Iran., p3-20.

10 National Standard of Iran (2006) The food and fodder microbiology. The method for counting of coagulase positive staphylococcus (S. aureus and the other Staph. spp.) The 3rd section (the most probable number MPN). p24-30.

11. Mohanty, N.N., Das, P., Pany, S.S., Sarangi, L.N., Ranabijuli, S., and Panda, H.K. (2013) Isolation and antibiogram of Staphylococcus, Streptococcus and E. coli isolates from clinical and subclinicalcases of bovine mastitis, Vet. World 6(10): 739-743.

12. Kumar, R. and Prasad, A. (2010) Detection of E.coli and Staphylococcus in milk and milk Products in and around Pantnagar, Vet. World.3 (11):495-496.

13. Pourhassan, M., and Taravat-Najafabadi, A.R.T. (2011) The spatial distribution of bacterial pathogens in raw milk consumption on Malayer City, Iran. Shiraz EMed J.12:2-10.

14. Jorgensen, H.J., Mork, T., Hogasen, H.R., and Rorvik, L.M. (2005) Enterotoxigenic Staphylococcus aureus in bulk milk in Norway, JAppl Microbiol. 99:158-166.

15. Foschino, R., Invernizzi, A., Barucco, R., and Stradiotto, K. (2007) Microbial composition, including the incidence of pathogens, of goat milk from the bergamo region of Italy during a lactation year, J Dairy Res.69 (2):213-225.

16. Thaker, H.C., Brahmbhatt, M.N.,and Nayak, J.B. (2012) Study on occurrence and antibiogram pattern of Escherichia coli fromrawmilk samples in Anand, Gujarat, India, Vet. World. 5(9): 556-559.

17. Przysucha, T., Grodzki, H., and Zdziarski, K. (2003)The influence of delivery system monthly milk supply and season on TBC in raw milk qualified to the highest quality classes. $J$ Polish Agr Univ; 68:115-22.

18. Bradley, A. J. (2002) Bovine mastitis an evolving disease, London. Vet. J.164: 116-128.

19. Jeykumar, M., Vinodkumar, G., Bashir, B.P. and Krovvidi,S. (2013) Antibiogram of mastitis pathogens in the milk of crossbred cows in Namakkal district, Tamil Nadu. Vet. World 6(6): 354-356.

20. Mhone, T.A., Matope, G. and Saidi, P.T. (2011) Aerobic bacterial, coliform, Escherichia coli and Staphylococcus aureus counts of raw and processed milk from selected smallholder dairy farms of Zimbabwe. Int J Food Microbiol 151:223-228.

21. Fotou, K., Tzora, A., Voidarou, C.h., Alexopoulos, A., Plessas, S., Avgeris, I., Bezirtzoglou, E., Akrida-Demertz, K. and Demertzis, P.G. (2011) Isolation of microbial pathogens of subclinical mastitis from raw sheep's milk of Epirus (Greece) and their role in its hygiene. Anaerobe. 17: 315-319.

22. Hill, B., Smythe, B., Lindsay, D. and Shepherd, J. (2012) Microbiology of raw milk in New Zealand. Int J Food Microbiol. 157: 305-308.

23. Rezaei, M., Karimi, F., Yahyaei, M., Javdani, H., Shahabi, A. and Farahi, A. (2013) The survey of microbial total count and prevalence of Escherichia coli in raw milk in Markazi Province, Iran. Res. Opin. Anim. Vet. Sci. 3 (12):474-477.

24. ISIRI (2008) Microbiology of milk and its products. Institute of Standards and Industrial Research of Iran, p2406.

\section{$* * * * * * * *$}

